\title{
ANALYSIS THE INFLUENCE OF ONLINE LEARNING ON STUDENTS' LEARNING ENTHUSIASM
}

\author{
Almira Faramadila Putri ${ }^{1)}$, Muhamad Sofian $\operatorname{Hadi}^{2)}$, Lidiyatul Izzah ${ }^{3)}$ \\ 1) Universitas Muhammadiyah Jakarta, Banten, Indonesia \\ E-mail:faramadila@gmail.com \\ 2) Universitas Muhammadiyah Jakarta, Banten, Indonesia \\ E-mail: m_sofianhadi@yahoo.com \\ 3) Universitas Muhammadiyah Jakarta, Banten, Indonesia \\ E-mail: izzahlidiyatul@gmail.com
}

\begin{abstract}
This research was created to explain in detail how the objective conditions of decreased enthusiasm for learning experienced by students in online learning during the covid-19 pandemic. This research uses quantitative methods with survey techniques. This research was conducted by involving 10 high school or vocational high school students. The data collection technique used in this study was a survey technique with a Likert scale. The survey was created in Microsoft Word and then distributed via WhatsApp to make it easier to access. The data analysis technique used in this study was to calculate the percentage of data on each indicator, then interpret the presentation score and analyze each indicator in detail. The inal results of the study indicate that the decline in learning of high school or vocational high school students is considered to be less good, it is obtained from the percentage score which amounts to $45 \%$. Hope this reseacrh can be an evaluation of various parties in implementing online learning, especially those involving motivation and enthusiasm for learning in it. In addition, it is hoped that it van be use as research material for other researchers in analyzing and developing students' enthusiasm for learning in online learning during emergencies.
\end{abstract}

Keywords: decreased enthusiasm for learning; online learning; covid-19 pandemic

\section{INTRODUCTION}

Currently, the entire world has been shocked by the corona virus (Covid-19) outbreak, 215 countries have been infected in various parts of the world. Of course, this pandemic has its own challenges for the community, including educational institutions. To eradicate or at least prevent the spread of Covid-19, the competent government has also restricted or even prohibited crowding, urged the public to carry out social distancing, wear mask and handsanitizer when leaving the house, and maintain distance, also known as physical distancing. No less important, always wash your hands with soap and running water. In this regard, the Ministry of Education and Culture of the Republic of Indonesia has banned offline learning or, more clearly, is advised not to carry out face-to-face learning or other terms conventional learning, and to be replaced by online learning through online applications that are easily accessible (Circular Letter Ministry of Education and Culture of Higher Education, 2020).

Learning online means that learning uses an internet network with a source of access or accessibility, connectivity, flexibility to bring up various types of learning interactions.
Sahu, (2020) the Covid-19 pandemic is a multidimensional problem facing the world, the impact was also felt in the education sector which led to a decline in quality learn in students. Sintema, (2020) this pandemic emergency period requires a system learning is replaced with online learning so that the learning process remains. this clearly changes the pattern of learning that requires teachers and education developers to provide learning and teaching materials students directly via digital remote devices take place.

The use of the internet and technology is able to change the way of conveying knowledge and can be an alternative to learning carried out in traditional classrooms. Online learning is learning that is able to bring together students and lecturers to carry out learning interactions with the help of the internet (Kuntarto, E., 2017).

The covid-19 pandemic in education has an significant impact on disrupted school activities and threatens them in the future.

If this pandemic in the long term does not end soon, it is not impossible that students will automatically feel the delay in the process of education and maturity growth. Students automatically do not get the education they deserve. 
Until now, almost all schools in Indonesia have started implementing distance teaching and learning activities by utilizing online applications such as Google Classroom, Quizizz, WhatsApp, YouTube, and others. Distance learning as known as online learning is an educational innovation as a challenge to the many varied learning resources available. The success of a media or learning model depends on the characteristics of each student. Nakayama revealed that from all literature in e-learning it is indicated that not all students can be successful in online learning, due to the learning environment and the characteristics of each student. (Nakayama M, et al., 2014).

Online learning certainly makes it easier for teachers and students to carry out the teaching and learning process. Students can have the flexibility of time to study anytime and anywhere. Can wear clothes freely, not even showering, it is not a problem, more flexible time, and many other advantages.

But no matter how easy online learning is, the impact of Covid-19 is felt in the community, for example, is the limited daily activities. This includes the learning of school students from kindergarten to college level.

And not just many advantages, there are many disadvantages too. This Covid-19 pandemic, the lockdowns, and its containment measures have affected the mental health of people around the world. Many students are suffering from anxiety and stress. Such as the psychological issues often happens on students when they try to adapt the online lessons. And of course many people complain that with this online learning, students' enthusiasm for learning decreases as well as parents who complain about online learning problems that are common in the community, especially those who are not well off. These problems include: not having enough money to buy quotas, unstable internet access, not being proficient in using gadgets or cellphones, and some even do not have the media to study online (gadget / handphone).

So teachers are required to be alert to this situation. Understand this situation for sure, the other most important thing is how to keep students who don't have gadgets able to keep up with the lessons. It can be by home visit or coming to school, but especially for students who do not have access or media for online learning.

According to (Selvi, 2010) online learning is often required to be more motivated to learn, because the learning environment often depends on the motivation and characteristics of each student related to curiosity and selfmotivation to involve in the learning process. Motivation is assessed as an important factor in learning success, as well as in this online or distance learning environment. So it is necessary to reconsider the motivation to learn in the environment of students who use technology (Harandi, 2015). Therefore, it is important for researchers in the world of education to examine more deeply about how students motivation in online learning, especially learning activities were carried out during the Covid-19 pandemic.

The purpose of this study is to obtain information about the causes of the decrease in learning enthusiasm for vocational / high school students during online learning in the pandemic and the solution to minimize the decrease in enthusiasm for learning.urrently, the entire world has been shocked by the corona virus (Covid-19) outbreak, 215 countries have been infected in various parts of the world. Of course, this pandemic has its own challenges for the community, including educational institutions. To eradicate or at least prevent the spread of Covid-19, the competent government has also restricted or even prohibited crowding, urged the public to carry out social distancing, wear mask and handsanitizer when leaving the house, and maintain distance, also known as physical distancing. No less important, always wash your hands with soap and running water. In this regard, the Ministry of Education and Culture of the Republic of Indonesia has banned offline learning or, more clearly, is advised not to carry out face-to-face learning or other terms conventional learning, and to be replaced by online learning through online applications that are easily accessible (Circular Letter Ministry of Education and Culture of Higher Education, 2020).

Learning online means that learning uses an internet network with a source of access or accessibility, connectivity, flexibility to bring up various types of learning interactions.

The research stated by Zhang et al., (2004) shows that the use of the internet and multimedia technology is able to change the way of conveying knowledge and can be an alternative to learning carried out in traditional classrooms. Online learning is learning that is able to bring together students and lecturers to carry out learning interactions with the help of the internet (Kuntarto, E. (2017).

The covid-19 pandemic in education has an significant impact on disrupted school activities and threatens them in the future.

If this pandemic in the long term does not end soon, it is not impossible that students will automatically feel the delay in the process of education and maturity growth. Students automatically do not get the education they deserve.

Until now, almost all schools in Indonesia have started implementing distance teaching and learning activities by utilizing online applications such as Google Classroom, Quizizz, WhatsApp, YouTube, and others.

Distance learning as known as online learning is an educational innovation as a challenge to the many varied learning resources available. The success of a media or learning model depends on the characteristics of each student. Nakayama revealed that from all literature in e-learning it is indicated that not all students can be successful in online learning, due to the learning environment and the characteristics of each student. (Nakayama M, Yamamoto H, 2007).

Online learning certainly makes it easier for teachers and students to carry out the teaching and learning process. Students can have the flexibility of time to study anytime and anywhere. (Revelation, 2020). Can wear clothes freely, not even showering, it is not a problem, more flexible time, and many other advantages.

But no matter how easy online learning is, the impact of Covid-19 is felt in the community, for example, is the limited daily activities. This includes the learning of school students from kindergarten to college level. 
And not just many advantages, there are many disadvantages too. This Covid-19 pandemic, the lockdowns, and its containment measures have affected the mental health of people around the world. Many students are suffering from anxiety and stress. Such as the psychological issues often happens on students when they try to adapt the online lessons. And of course many people complain that with this online learning, students' enthusiasm for learning decreases as well as parents who complain about online learning problems that are common in the community, especially those who are not well off. These problems include: not having enough money to buy quotas, unstable internet access, not being proficient in using gadgets or cellphones, and some even do not have the media to study online (gadget / handphone).

So teachers are required to be alert to this situation. Understand this situation for sure, the other most important thing is how to keep students who don't have gadgets able to keep up with the lessons. It can be by home visit or coming to school, but especially for students who do not have access or media for online learning.

According to (Selvi, 2010) online learning is often required to be more motivated to learn, because the learning environment often depends on the motivation and characteristics of each student related to curiosity and selfmotivation to involve in the learning process. Motivation is assessed as an important factor in learning success, as well as in this online or distance learning environment. So it is necessary to reconsider the motivation to learn in the environment of students who use technology (Harandi, 2015). Therefore, it is important for researchers in the world of education to examine more deeply about how students' motivation in online learning, especially learning activities were carried out during the Covid-19 pandemic.

The purpose of this study is to obtain information about the causes of the decline in learning enthusiasm for vocational / high school students during online learning during the pandemic and how the solution is to minimize the decline in enthusiasm for learning.

\section{RESEARCH METHODOLOGY}

This research used quantitative methods in terms of data collection and evaluation. Nenty, (2009) said that quantitative research methods are useful for uncovering general truths and principles in the form of relationships between variables or phenomena. One of the characteristics of quantitative research is data analysis techniques that use quantitative techniques (statistics) objectively (Creswell, 2010).

Quantitative methods emphasize statistical and objective measurement, also numerical or mathematical analysis of data collected through opinion polls, questionnaires and surveys, or the processing of pre-existing statistical data through the use of computational techniques. The focus of quantitative research is to collect numerical data and generalize or explain specific phenomena in a population. (Babbie, 2010)

This type of research is a survey method. The essence of the survey method can be interpreted as "asking individuals on one or more topics, and then describing their answers" (Jackson, 2011, p.17).
Survey research is valued as a method that describes specific aspects quantitatively from a certain population, so that data collection is carried out on a group of people whose results can be generalized to a certain population. This survey method is suitable to be used to reveal the decrease in student enthusiasm for online learning during the Covid-19. pandemic. The subjects in this study were 10 students of SMK / SMA and equivalent who received online learning during the Covid19 pandemic.

The instrument that used in this research method was surveying the data. The survey is in the form of a questionnaire in Microsoft Word and then shared on WhatsApp. The survey aims to reveal in detail about the decline in student enthusiasm for learning online during the Covid-19 pandemic, this type of survey uses a Likert scale.

(Sugiyono, 2018) said that the Likert scale is a tool to measure the opinions, attitudes and perceptions of an individual or group of people towards social phenomena. We present the Likert scale table as follows.

TABLE I

FONT SIZES FOR PAPERS

\begin{tabular}{cc} 
Assessment Criteria & Assessment Scale \\
\hline Yes (Agree) & 10 \\
No (Disagree) & 1 \\
\hline
\end{tabular}

In addition, in this study, data analysis techniques were carried out by calculating the percentage of the scores that have been obtained, the following is the formula for calculating the percentage as follows.

$$
\text { Rumus Index } \%=\frac{\mathrm{T} . \text { Score }}{\text { Score } \max } \times 100
$$

Fig. 1 Percentage Score Formula of Respondents

Explaination:

T. Score : (Number of answers Agree x highest score) + (Number of answers Disagree $\mathrm{x}$ lowest score) Score max : Number of respondents $\mathrm{x}$ highest score

From the percentage results obtained, then the interpretation of the scores is carried out based on the interval table below.

TABLE III

INTERPRETATION SCORE CRITERIA

\begin{tabular}{cc}
\hline Precentage & Explaination \\
\hline $0 \%-50 \%$ & Not Good \\
$50 \%-100 \%$ & Good \\
\hline
\end{tabular}

The calculation table above becomes the basis for further analyzing and concluding how high school / vocational school students' learning enthusiasm is equal in online learning during the Covid-19 Pandemic.

\section{FINDING AND DISCUSSION}


A survey of reducing enthusiasm for learning was given to 10 SMA / SMK students and equivalent, with details of 7 SMK students and 3 SMA students. Following the survey results are described in the table below.

TABLE IIIII

RESULT SURVEY OF THE DECREASE ENTHUSIASM IN ONLINE LEARNING

\begin{tabular}{|c|c|c|c|c|}
\hline No. & Indicator & Aspect & Presentage & Criteria \\
\hline \multirow{4}{*}{1.} & \multirow{4}{*}{ Media } & $\begin{array}{l}\text { Google } \\
\text { Classroom }\end{array}$ & $90 \%$ & Good \\
\hline & & Quizizz & $70 \%$ & Good \\
\hline & & $\begin{array}{l}\text { WhatsApp } \\
\text { Group }\end{array}$ & $40 \%$ & $\begin{array}{c}\text { Not } \\
\text { Good }\end{array}$ \\
\hline & & Books & $100 \%$ & Good \\
\hline \multirow[t]{3}{*}{2.} & \multirow[t]{3}{*}{ Enthusiasm } & $\begin{array}{l}\text { Student interest } \\
\text { in answering } \\
\text { on question in } \\
\text { online learning }\end{array}$ & $10 \%$ & $\begin{array}{l}\text { Not } \\
\text { Good }\end{array}$ \\
\hline & & $\begin{array}{l}\text { Student interest } \\
\text { in providing } \\
\text { material on } \\
\text { online learning }\end{array}$ & $30 \%$ & $\begin{array}{l}\text { Not } \\
\text { Good }\end{array}$ \\
\hline & & $\begin{array}{l}\text { Students' } \\
\text { desire to } \\
\text { recorrect the } \\
\text { wrong answer } \\
\text { test and } \\
\text { resubmit it }\end{array}$ & $80 \%$ & Good \\
\hline \multirow[t]{2}{*}{3.} & \multirow[t]{2}{*}{$\begin{array}{l}\text { Compre- } \\
\text { hension }\end{array}$} & $\begin{array}{l}\text { Comprehension } \\
\text { student of } \\
\text { online learning } \\
\text { by delivering } \\
\text { material via } \\
\text { video }\end{array}$ & $70 \%$ & Good \\
\hline & & $\begin{array}{l}\text { Aqcuisition of } \\
\text { knowledge and } \\
\text { experience in } \\
\text { doing the } \\
\text { online } \\
\text { assigment }\end{array}$ & $20 \%$ & $\begin{array}{l}\text { Not } \\
\text { Good }\end{array}$ \\
\hline 4. & Curiosity & $\begin{array}{l}\text { Students' } \\
\text { awareness of } \\
\text { the lack of } \\
\text { attention online } \\
\text { class material } \\
\text { and prefer } \\
\text { browsing the } \\
\text { answer of the } \\
\text { assigment }\end{array}$ & $40 \%$ & $\begin{array}{c}\text { Not } \\
\text { Good }\end{array}$ \\
\hline
\end{tabular}

The table above shows that several aspects that are considered in viewing learning media as indicators include:

1) Learning by using Google Classroom with a percentage score of $90 \%$ is a good criterion, indicating that students tend to be interested in providing material and solving questions through Google Classroom
2) Learning using Quizizz gets a percentage of $70 \%$ which is a good criterion, even though students are indicated to prefer Google Classroom

3) Learning through WhatsApp Group media gets a percentage of $40 \%$ which shows that students are less interested in learning through WhatsApp Group

4) Learning to use books with a percentage of $100 \%$ indicates that students actually want to avoid online learning, many internet problems and cost are the main factors

The second indicator related to a decrease in enthusiasm for learning is student enthusiasm with the following aspects:

1) That students are actually more enthusiastic if learning is carried out offline or face-to-face. But because of the pandemic, students are required to do distance learning

2) Student interest in providing material in online learning gets a percentage of $30 \%$ which can be seen that students remain prefers delivery of material offline

3) The desire of students to correct wrong work results and resubmit get a pretty good percentage of $80 \%$, it is indicated that students still pay attention to their respective competency scores

The third indicator is Comprehension with the aspects:

1) Comprehension in online learning by delivering material through video gets a percentage of $70 \%$, delivery of material through video is important because it will help students achieve good learning outcomes

2) The acquisition of knowledge and experience in online assignments to obtain The percentage was 20\%, indicating that students felt that they did not gain experience due to a decrease in enthusiasm for learning, in the end students chose to cheat or copy a friend's work

The last indicator related to learning motivation is curiosity of the student. Fauzi, et al., (2017) Curiosity is a very important initial capital in the process learning, with high curiosity the desire will encourage students in finding what he wants to know. with 1 aspect, namely the awareness of students in not paying attention to online material and preferring to browse in doing questions to get a percentage of $40 \%$, it turns out that students still have less awareness of online material provided by the teacher.

\section{IV.CONCLUSIONS}

Based on the results of data analysis that have been previously submitted, it can be concluded that from 4 indicators of decreased student enthusiasm for learning, namely learning media, enthusiasm, understanding, and curiosity, the average percentage score is $55 \%$ including good criteria, and the remaining $45 \%$ indicates that students enthusiasm for learning in online learning is still lacking. From the brief questions I asked the respondents, it is known that the decline in their enthusiasm for learning is caused by boredom of students due to monotonous activities, besides that, students feel lonely because they stay at home during the pandemic, the lack of learning facilities at home is also a factor that students complain about. in online learning activities 
From the problems described above, it is hoped that students can instill strong motivation in learning and not make these activities a burden during a pandemic like today.

In addition, conditioning a safe and comfortable place to study is also important to maintain a good mood for studying.

Don't hesitate to ask. It is possible for students to have difficulties, so it is hoped that students will continue to actively communicate with teachers and friends through social media.

\section{REFERENCES}

Al-Ansori, A. N. (2020). Learning at Home Due to Corona COVID-19, These Are the Opinions and Expectations of Indonesian Children. Liputan6. https://m.liputan6.com/health/read/4224969/

belajar-di-rumah-akibat- corona-covid-19-

inipendapat-dan-harapan-anak-indonesia

Ashari, M. (2020). Learning process Online in the midst of e Spread of the Corona Virus is Considered Not Maximum. PikiranRakyatcom. https://www.pikiranrakyat.com/pendidikan/ pr01353818/prosespembejalaran- daring-di-tengahantisipasipenyebaran-viruscorona-dinilaibelummaksimal

Babbie, Earl R. The Practice of Social Research. 12th ed. Belmont, CA: Wadsworth Cengage, 2010; Brians, Craig Leonard et al. Empirical Political Analysis: Quantitative and Qualitative Research Methods. 8th ed.

Circular Letter Ministry of Education and Culture of Higher Education, (2020). Circular Number 3 of 2020 concerning Prevention of COVID-19 in Education Units.

Creswell, J. W. (2010). Research Design: Qualitative, Quantitative, and Mixed Approaches. Yogyakarta: Pustaka Pelajar.

Dewi, W. A. F. (2020). The Impact of Covid-19 on the Implementation of Online Learning in Primary Schools. Educative: Journal of Educational Sciences, 2(1), 55-61. Retrieved from https://edukatif.org/index.php/edukatif/index.

Fauzi, A. R., Zainuddin, \& Atok, R. Al. (2017). Penguatan Karakter Rasa Ingin Tahu dan Peduli Sosial melalui Discovery Learning. Jurnal Teori Dan

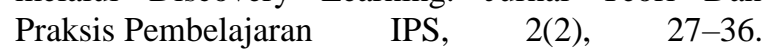
http://journal2.um.ac.id/index.php/jtppips/\%0AAchm ad.

Harandi, S. R. (2015). Effects of E-learning on Students' Motivation. Procedia - Social and Behavioral Sciences, 181, 423-430. https://doi.org/10.1016/j.sbspro.2015.04.905.

Jackson, S.L. (2011) "Research Methods and Statistics: A Critical Approach", 4th edition, Cengage Learning, p. 17

Kuntarto, E. (2017). Kefektifan Model Pembelajaran Daring Dalam Perkuliahan Bahasa Indonesia Diperguruan Tinggi" Journal Indonesian Language
Education and Literature / ILE\&E/Vol.3 No. 1

Nakayama, M., Mutsuura, K., \& Yamamoto, H. (2014). Impact of Learner's Characteristics and Learning Behaviour on Learning Performance during a Fully Online Course. Electronic Journal of E-Learning, 12(4), 394-408. www.ejel.org.

Nenty, H. J. (2009). Writing a Quantitative Research Thesis. International Journal of Educational Sciences, 1(1), 19-32. 89972.

https://doi.org/10.1080/09751122.2009.118

Sahu, P. (2020). Closure of Universities Due to Coronavirus Disease 2019 (COVID-19): Impact on Education and Mental Health of Students and Academic Staff. Cureus, 2019(April). https://doi.org/10.7759/cureus.7541.

Selvi, K. (2010). Motivating Factors in Journal of Educational Sciences, 1(1), 19-32. https://doi.org/10.1080/09751122.2009.118 89972.

Sintema, E. J. (2020). Effect of COVID-19 on the Performance of Grade 12 Students: I mplications for STEM Education. Eurasia Journal of Mathematics, Science and Technology Education, 16(7), 1-6. https://doi.org/10.29333/ejmste/7893

Sugiyono. (2018). Quantitative Research Methods, Qualitative, and R \& D. Bandung: CV. Alfabeta. 